\title{
Determination of The Anxiety Level in Pregnant Women Who Administer to The Obstetrics Clinic Within The COVID-19 Pandemia Period
}

\section{COVID-19 Pandemisi Döneminde Kadın Doğum Kliniğine Başvuran Gebelerde Anksiyete Düzeyinin Belirlenmesi}

Emine Turen Demir ${ }^{1}$,

Fatma Kilic ${ }^{1}$

${ }^{1}$ Necmettin Erbakan University, Meram Faculty of Medicine, Department of Obstetrics and Gynecology, Konya, Turkey

Geliş Tarihi/Received: 13 July 2020 Kabul Tarihi/Accepted: 21 August 2020

Address correspondence to: Emine Turen Demir, Necmettin Erbakan University, Meram Faculty of Medicine, Department of Obstetrics and Gynecology, Konya,Turkey e-mail: eturen1@hotmail.com

\section{ORCID}

\section{Emine Turen Demir}

https://orcid.org/0000-0001-5510-4411 Fatma Kilic

https://orcid.org/0000-0002-9335-3552
Öz

Amaç: Pandemi olarak ilan edilen COVID-19 enfeksiyonu her geçen gün artan morbidite ve mortalite oranlarının yanında stress ve kaygı düzeylerinde de belirgin artışa neden olmuştur. Bu çalışmada COVID-19 enfeksiyonunun gebelerde anksiyetine düzeyine olan etkisini belirlemek amaçlanmıştır.

Hastalar ve Yöntem: Bu çalışmada rutin gebelik kontrolü için Haziran 2020 ayı boyunca ayaktan polikliniğe başvuran gebelere COVID-19'a bağlı olabilecek kaygılarını belirlemeye yönelik yapılandırılmış bir anket ve Beck anksiyete ölçeği uygulanmıștır. Obstetrik acil nedenler ile başvuran gebeler ve obstetrik açıdan riskli bulunan gebeler çalışmaya dahil edilmemiştir.

Bulgular: Çalışmaya 177 gebe dahil edilmiş ve gebeler Beck anksiyete ölçeğinden aldıkları puana göre dört gruba ayrılmıştır. Gebelerin anksiyete düzeyi \%44,6 olarak bulunmuştur. Doğum anında ailesinin yanında olamama intimali ve COVID-19' a bağlı ölme korkusu istatistiksel olarak anlamlı şekilde yüksek anksiyete düzeyleri ile ilişkili bulunmuştur.

Sonuç: Bu süreçte gebelerin perinatoloji, yenidoğan, yoğun bakım uzmanlarından oluşan multidisipliner bir ekip tarafından takibine ek olarak psikososyal desteğin de sağlanması önem arz etmektedir.

Anahtar Kelimeler: Anksiyete, COVID-19, gebelik

\section{Abstract}

Aim: The COVID-19 infection, declared as a pandemic, has caused a significant increase in stress and anxiety levels as well as increasing morbidity and mortality rates. In this study, it was aimed to determine the effect of COVID-19 infection on anxiety level in pregnant women.

Patients and Methods: In this study, a questionnaire and Beck anxiety scale were applied to pregnant women who referred to outpatient clinic for routine pregnancy control in June 2020 to determine their concerns that may be related to COVID-19. Pregnant women admitted with obstetric emergencies and obstetric risk were not included in the study.

Results: 177 pregnant women were included in the study and the pregnant women were divided into four groups according to their score on Beck anxiety scale. Anxiety level of pregnant women was $44.6 \%$. The possibility of not being with his family at the time of birth and the fear of death due to COVID-19 were statistically significantly associated with higher anxiety levels.

Conclusions: In this process, it is important to provide psychosocial support in addition to the follow-up of pregnant women by a multidisciplinary team consisting of perinatology, newborn and intensive care specialists.

Key words: Anxiety, COVID-19, pregnancy
Cite this article as: Demir ET, Kilic F. Determination of The Anxiety Level in Pregnant Women Who Administer to The Obstetrics Clinic Within The Covid-19 Pandemia Period. Selcuk Med J 2020;36(4): 352-356

“This article is licensed under a Creative Commons Attribution-NonCommercial 4.0 International License (CC BY-NC 4.0)" Disclosure: None of the authors has a financial interest in any of the
products, devices, or drugs mentioned in this article. The research was
not sponsored by an outside organization. All authors have agreed to allow
full access to the primary data and to allow the journal to review the data
if requested. 


\section{INTRODUCTION}

In December 2019, COVID-19 infection caused by the treatment-resistant pneumonia cases, caused by the coronavirus family, SARS-CoV-2, which originated in Wuhan, China, was declared as a pandemic in March 2020 by the World Health Organization. The disease, which is rapidly spreading and has serious morbidity and mortality rates, has had significant effects on the mental health of the society as well as physical damage. Similar to the previous MERS infection, posttraumatic stress disorder and depressive disorders have been commonly seen $(1,2)$. In addition, research during previous similar outbreaks (SARS and MERS) has shown that pregnant women are more likely to be psychologically affected (3). Normally, the idea that something can go wrong by means of hormonal changes during pregnancy creates a heavy burden for pregnant women and increases anxiety levels. In this pandemic process, the fear of infecting the baby, the idea of being in the risk group due to pregnancy, and the restrictions due to the pandemic (curfew, inability to access health services, etc.) are also seen as factors that may increase anxiety levels during pregnancy. Based on this, our aim in this study is to determine the effect of COVID-19 infection on anxiety level in pregnant women.

\section{PATIENTS AND METHODS}

In this study, we aimed to determine the level of anxiety caused by COVID-19 in pregnant women who applied to our clinic for routine pregnancy follow-up. The pregnant women who applied to the outpatient clinic for routine control during June 2020 were given information about the study and their consents were obtained, and filled out a questionnaire to determine their concerns related to COVID-19, such as age, education level, occupation, family structure, gestational week, and demographic information. At the same time, Beck anxiety scale (4), which consisted of twenty one items, evaluated the frequency of anxiety symptoms over the past month with a 4-point Likert scale ranging from 0 (none) to 3 (seriously). The total score of the Beck anxiety scale ranges from 0 to 63 , and increasing scores indicate that the level of anxiety is more serious. Pregnant women admitted with obstetric emergency reasons and pregnant women who were found obstetrically risky were excluded in the study. This study was approved by the Ethics Committee of Necmettin Erbakan University Medical Faculty and informed consent was obtained from each participant prior to starting the investigation. The data obtained from the study were analyzed using the SPSS 20.0 package program. $P<0.05$ was considered statistically significant. Descriptive analyzes were conducted to define the anxiety levels, demographic characteristics and information about COVID-19 of pregnant women. Chi-square test $(X 2)$ was used to compare the demographic characteristics of pregnant women according to their anxiety levels. Multivariate logistic regression analysis was used to show the relationship between factors that may cause COVID19-related anxiety and anxiety levels in pregnant women.

\section{RESULTS}

177 pregnant women were included in the study, and they were divided into four groups according to the score they got from Beck anxiety scale. According to this, $55.4 \%$ of pregnant women had no symptoms of anxiety (0-7 points). $30.5 \%$ were mild ( $8-15$ points), $11.3 \%$ were moderate (16-25 points), and $2.8 \%$ were severe (26-63 points) (Table 1$)$.

The average age of pregnant women participating in the study was $27.4(18-41)$, the average number of pregnancies was $2.3(1-7)$ and the average week of gestation was 24.9 (5-39). $57.8 \%$ of the mother candidates and $60.5 \%$ of the father candidates were high school and university graduates. $72.3 \%$ of pregnant women were housewives. $71.8 \%$ of the pregnant women had a nuclear family structure and $66.1 \%$ of them were living in the city center.

In the immediate vicinity of the four pregnant women $(2.3 \%)$ who participated in the study, there were 19 positive patients with COVID-19. $53.1 \%$ of pregnant women think it is safe to continue their pregnancy controls during the pandemic, $45.2 \%$ of the pregnant women have continued their routine controls, $49.2 \%$ have extended the time between controls, $5.6 \%$ have

Table 1. Anxiety levels of pregnant women

\begin{tabular}{|c|c|c|c|c|c|}
\hline \multicolumn{6}{|c|}{ Anxiety Level } \\
\hline & Normal & Mild & Moderate & Severe & Total \\
\hline Number (N) & 98 & 54 & 20 & 5 & 177 \\
\hline Ratio (\%) & 55.4 & 30.5 & 11.3 & 2.8 & 100 \\
\hline
\end{tabular}


never been to pregnancy control. Demographic data of pregnant women according to their anxiety levels are summarized in Table 2.

In our study, the relationships between COVID-19 fear of death due to anxiety levels, fear of losing his / her relatives, the possibility of his family not being at birth, the possibility of forced cesarean delivery, the possibility of virus transmission to the baby, the disease may be more severe in pregnant and newborn and the anxiety levels were examined. In our study, the relationship between fear of death from COVID-19, fear of losing a close relative, the possibility of not being with her family at birth, the possibility of not being with her family in an emergency, the possibility of forced cesarean delivery, the possibility of transmission of the virus to the baby, the severity of the disease in pregnant and newborn, and anxiety levels were examined. Among these, the possibility of not being with his family at the time of birth and the fear of death due to COVID-19 were statistically significantly associated with high anxiety levels. Factors that may affect Beck anxiety scale and their relationship with demographic characteristics are shown in Table 3.

\section{DISCUSSION}

Related to fear of birth, reduced effective coping strategies, cesarean delivery, etc. anxiety levels are

Table 2. Demographic data of pregnant women according to their anxiety levels

\begin{tabular}{|c|c|c|c|c|}
\hline \multicolumn{5}{|c|}{ Anxiety Level } \\
\hline & $\begin{array}{l}\text { Normal } \\
\text { (0-7 point) }\end{array}$ & $\begin{array}{l}\text { Mild } \\
\text { (8-15 point) }\end{array}$ & $\begin{array}{l}\text { Moderate } \\
\text { (16-25 point) }\end{array}$ & $\begin{array}{l}\text { Severe } \\
\text { (26-63 point) }\end{array}$ \\
\hline \multicolumn{5}{|l|}{$\overline{\text { Age }}$} \\
\hline $18-25$ & $36(20.3)$ & $26(14.7)$ & $9(5.1)$ & $1(0.6)$ \\
\hline $26-35$ & $51(28.8)$ & $23(13)$ & $8(4.5)$ & $4(2.3)$ \\
\hline 35 And Above & $11(6.2)$ & $5(2.8)$ & $3(1.7)$ & $0(0)$ \\
\hline \multicolumn{5}{|l|}{ Education } \\
\hline Primary-Secondary School & $37(20.9)$ & $29(16.4)$ & $7(4)$ & $0(0)$ \\
\hline High School & $20(11.3)$ & $9(5.1)$ & $6(3.4)$ & $1(0.6)$ \\
\hline University & $41(23.2)$ & $16(9)$ & $7(4)$ & $4(2.3)$ \\
\hline \multicolumn{5}{|l|}{ Occupation } \\
\hline Housewife & $70(39.5)$ & $41(23.2)$ & $15(8.5)$ & $2(1.1)$ \\
\hline Fixed Income Business & $10(5.6)$ & $7(4)$ & $1(0.6)$ & $1(0.6)$ \\
\hline Self-Employment & $18(10.2)$ & $6(3.4)$ & $4(2.3)$ & $2(1.1)$ \\
\hline \multicolumn{5}{|l|}{ Sort of Family } \\
\hline Nuclear Family & $72(40.7)$ & $37(20.9)$ & $13(7.3)$ & $5(2.8)$ \\
\hline Extended Family & $12(6.8)$ & $11(6.2)$ & $2(1.1)$ & $0(0)$ \\
\hline Other & $14(7.9)$ & $6(3.4)$ & $5(2.8)$ & $0(0)$ \\
\hline \multicolumn{5}{|l|}{ Residency } \\
\hline City & $67(37.9)$ & $36(20.3)$ & $11(6.2)$ & $3(1.7)$ \\
\hline Town & $26(14.7)$ & $13(7.3)$ & $5(2.8)$ & $2(1.1)$ \\
\hline Village & $5(2.8)$ & $5(2,8)$ & $4(2.3)$ & $0(0)$ \\
\hline \multicolumn{5}{|l|}{ Number of Pregnancy } \\
\hline Nulliparous & $41(23.2)$ & $22(12.4)$ & $8(4.5)$ & $4(2.3)$ \\
\hline Multiparous & $57(32.2)$ & $32(18.1)$ & $12(6.8)$ & $1(0.6)$ \\
\hline \multicolumn{5}{|l|}{ Trimesters of Pregnancy } \\
\hline 1st Trimester & $37(20.9)$ & $0(0)$ & $3(1.7)$ & $1(0.6)$ \\
\hline 2nd Trimester & $55(31.1)$ & $0(0)$ & $5(2.8)$ & $1(0.6)$ \\
\hline 3rd Trimester & $6(3.4)$ & $54(30.5)$ & $12(6.8)$ & $3(1.7)$ \\
\hline \multicolumn{5}{|l|}{ CoVID-19+in Immediate Vicinity } \\
\hline Yes & $3(1.7)$ & $1(0.6)$ & $0(0)$ & $0(0)$ \\
\hline No & $95(53.7)$ & $53(29.9)$ & $20(11.3)$ & $5(2.8)$ \\
\hline \multicolumn{5}{|l|}{ Attend to Medical Examination } \\
\hline Safe & $47(26.6)$ & $33(18.6)$ & $12(6.8)$ & $2(1.1)$ \\
\hline Unsafe & $51(28.8)$ & $21(11.9)$ & $8(4.5)$ & $3(1.7)$ \\
\hline \multicolumn{5}{|l|}{ Control Frequency } \\
\hline Routine Control & $46(26)$ & $19(10.7)$ & $13(7.3)$ & $2(1.1)$ \\
\hline Prolonged Control Interval & $46(26$ & $33(18.6)$ & $6(3.4)$ & $2(1.1)$ \\
\hline Not Attended & $6(3.4)$ & $2(1.1)$ & $1(0.6)$ & $1(0.6)$ \\
\hline
\end{tabular}


Table 3. Regression analysis for anxiety

\begin{tabular}{lll}
\hline & $\mathbf{T}$ & $\mathbf{P}$ \\
\hline Age & -.128 & .898 \\
Education & 1.328 & .186 \\
Occupation & .743 & .459 \\
Residency & 1.816 & .071 \\
Sort of Family & .476 & .634 \\
Number of Pregnancy & -.262 & .794 \\
Trimesters of Pregnancy & 8.226 & .030 \\
COVID-19 + in Immediate Vicinity & 1.025 & .307 \\
Safety of Doctor Visit & -.529 & .598 \\
Control Frequency & -.803 & .423 \\
Cesarean Section in Pandemic Period & .496 & .621 \\
Family Presence at Birth & -2.201 & .029 \\
Fear of Getting Infected with COVID-19 & -.208 & .836 \\
Fear of Death Due To COVID-19 & -1.883 & .020 \\
Fear of Losing Her Baby Due to COVID-19 & -.210 & .834 \\
Fear of Losing Family Member Due to COVID-19 & .049 & .961 \\
COVID-19 Passes from Mothers to Babies & .453 & .651 \\
COVID-19 is More Severe in Pregnant Women & .401 & .689 \\
COVID-19 is More Severe in Young Children & -.307 & .759 \\
\hline
\end{tabular}

observed to be high during pregnancy. A meta-analysis published in 2017 reported a prevalence of $15.2 \%$ for any anxiety disorder and $22.9 \%$ for anxiety symptoms during pregnancy. In addition, it was observed that the incidence of anxiety increased in direct proportion with the week of gestation (5). To the authors best knowledge our study is the first one to show the effect of COVID-19 infection on pregnant women. In our study, the anxiety level of pregnant women during the pandemic process was found to be $44.6 \%$ and this situation was thought to be caused by infection. Similar to other studies, it was found that anxiety levels increased significantly as gestational week increased $(p=.030)$. In addition to factors such as the approach of birth, changing hormonal conditions; the fear of being infected, the lack of a proven treatment and vaccine, the fear of experiencing food shortages, decreasing number of disinfectants and masks, and the curfew due to a pandemic also contribute to this situation. In our study, it was seen that fear of death due to COVID-19 significantly increased anxiety levels of pregnant women $(p=.020)$. However, the posibility of being infected with COVID-19, the fear of losing a baby did not affect their anxiety levels, but the fear of losing a family member due to COVID-19 increased their anxiety levels in people who had COVID-19 positive individuals in the immediate vicinity. Having curfews, encouraging the public to stay home at all times through press-social media, and announcing that the disease is similar to the normal population in pregnant women and that the disease rates are lower in children were comforting factors for pregnant women, but if infected with COVID-19, fear of death increased their anxiety levels. A study to evaluate the symptoms of anxiety in pregnant women living in quarantine conditions in Greece due to the COVID-19 outbreak showed that duration of quarantine is an independent risk factor for anxiety in pregnancy (6). In our study, the probability of her family not being present at birth was associated with high anxiety levels in pregnant women $(p=.029)$, and this fear was found to be higher especially when birth was closer, that is, in the third trimester, The mother candidate, who is afraid of not being able to afford her baby, is worried about the possibility that her parents may not be present at birth or they become infected because of the curfew during the period when she needs the support of her family most.

Although the risk of infection in hospital is higher, the majority of pregnant women $(53.1 \%)$ thought that pregnancy follow-up was safe during the pandemic period. However, as the level of education increased, the idea that it was not safe to go for control was dominant. While $45.2 \%$ of pregnant women continued their routine pregnancy controls, $49.2 \%$ of them extended the period between pregnancy controls. $5.6 \%$ of them never went to pregnancy control in the past period. In addition, as the gestational week progressed, the rate of attending to routine control increased. Anxiety about the baby's health is thought to be effective in keeping pregnant women to attend controls. 
Although studies are carried out to identify the effects of the infection on pregnancy and to determine the complications of pregnancy, studies showing how pregnant women are psychologically affected by this pandemic process are limited. However, studies have shown that maternal stress and anxiety levels are associated with preeclampsia, preterm delivery, low birth weight, low APGAR score, increased hyperemesis gravidarum (7-12). Therefore, the psychological effects of this process, which causes anxiety levels to increase, are very important for both mother and fetus health.

As a result, COVID-19 had negative effects on community mental health and pregnant women were exposed to anxious factors related to their pregnancy in addition to these social anxious factors. Perinatal mental health is a leading public health problem due to its negative effects on the mother and baby and if it is left untreated, it can cause significant damage to public health. For this reason, it is important to provide psychosocial support in addition to the followup of pregnant women by a multidisciplinary team consisting of perinatology, newborn and intensive care specialists during the pandemic. Our study was conducted in a limited time period and further studies are needed to evaluate complications related to the pandemic process over a long period of time.

Conflict of interest: Authors declare that there is no conflict of interest between the authors of the article.

Financial conflict of interest: Authors declare that they did not receive any financial support in this study.

Address correspondence to: Emine Turen Demir, Necmettin Erbakan University, Meram Faculty of Medicine, Department of Obstetrics and Gynecology, Konya, Turkey Telephone: 03323236415

e-mail: eturen1@hotmail.com

\section{REFERENCES}

1. Mak IV, Chu MC, Pan PC, et al. Long-term psychiatric morbidities among SARS survivors. Gen Hosp Psychiatry 2009;31(4):318-26.

2. Lee SM, Kang WS, Cho AR, et al. Psychological impact of the 2015 MERS outbreak on hospital workers and quarantined hemodialysis patients. Compr Psychiatry 2018;87:123-7.

3. Schwartz DA, Graham AL. Potential maternal and infant outcomes from coronavirus 2019- NCOV (SARS-CoV-2) infecting pregnant women: Lessons from SARS, MERS, and other human coronavirus infections. Viruses 2020;12(2):194

4. Ulusoy $M$, Şahin $N$, Erkmen $H$. Turkish version of the Beck anxiety inventory: Psychometric properties. J Cogn Psychotherapy 1998;12:163-72.

5. Dennis CL, Falah-Hassani K, Shiri R. Prevalence of antenatal and postnatal anxiety: Systematic review and meta-analysis. Br J Psychiatry 2017;210:315-23.

6. Dagklis T, Tsakiridis I, Mamopoulos A, et al. Anxiety during pregnancy in the era of the COVID-19 pandemic. (4/25/2020). Available at SSRN: https://ssrn.com/abstract $=3588542$

7. Qiao Y, Wang J, Li J, et al. Effects of depressive and anxiety symptoms during pregnancy on pregnant, obstetric and neonatal outcomes: A follow-up study. Journal of Obstetrics and Gynaecology 2012;32(3):237-40.

8. Field T, Diego M, Hernandez-Reif $M$, et al. Comorbid depression and anxiety effects on pregnancy and neonatal outcome. Infant Behavior and Development 2010;33(1):23-9.

9. Rubinchik SM, Kablinger AS, Gardner JS. Medications for panic disorder and generalized anxiety disorder during pregnancy. Prim Care Companion J Clin Psychiatry 2005;7(3):100-5.

10. Alder J, Fink N, Bitzer J, et al. Depression and anxiety during pregnancy: A risk factor for obstetric, fetal and neonatal outcome? A critical review of the literature. J Matern Fetal Neonatal Med 2007;20(3):189-209.

11. Littleton HL, Breitkopf CR, Berenson AB. Correlates of anxiety symptoms during pregnancy and association with perinatal outcomes: A meta-analysis. Am J Obstet Gynecol 2007;196(5):424-32.

12. Grigoriadis S, Graves L Peer M, et al. Maternal anxiety during pregnancy and the association with adverse perinatal outcomes: Systematic review and meta-analysis. J Clin Psychiatry 2018;79(5):17r12011. 